\title{
SOME KINETIC DEPENDENCE OF ELECTROHYPERFILTRATION METHOD OF PURIFICATION OF WASTEWATER FROM IRON IONS
}

\author{
A. A. Levin ${ }^{1}$, O. A. Abonosimov ${ }^{1}$, S. I. Lazarev ${ }^{1}$, \\ O. A. Kovaleva ${ }^{1}$, I. V. Khorokhorina ${ }^{2}$, M. A. Kuznetsov ${ }^{1}$ \\ Departments of Applied Geometry and Computer Graphics (1), \\ Nature Management and Environment Protection (2), \\ TSTU,Tambov,Russia; geometry@mail.nnn.tstu.ru
}

Keywords: coefficient of detention; current density; installation; kinetic dependencies; membrane; output stream; separation; solution.

\begin{abstract}
The possibility of applying electrohydraulic filtration separation during wastewater treatment from iron ions is shown. The research was aimed to study the impact of the operating parameters of the separation process of the test solution on some of the kinetic characteristics (current-voltage characteristics, output flux, retention factor, diffusion permeability coefficient and sorption capacity of MGA-80, MGA-95 and MGA-100 membranes) in electrohydraulic filtration sewage separation of galvanic metalworking industries. The regularities of the change in the retention factor, the output flux, the diffusion permeability coefficient, and the sorption capacity of membranes depending on the current density, the magnitude of the transmembrane pressure, the temperature and the type of membrane for the solution are determined. The interpretation and generalization of the experimental dependences of some kinetic dependencies on the parameters of the separation process are presented.
\end{abstract}

Widely-used methods of protecting metals from destruction include electrodeposited metal coatings applied to the surface of metal products as well as semifinished sheets, pipes, wires, etc. These methods are applied in technological cycles of most machine-building, metalworking, instrument-making, repair and other enterprises. Metal-coatings protection is used to improve corrosion resistance and wear resistance and improve the decorative appearance of products. For example, galvanic coatings are applied with aqueous solutions or solutions of molten salts by means of an electric direct current. At the same time, waste water forms cannot be discharged into water bodies and sewerage without carrying out cleaning processes. Traditional mechanical and biochemical cleaning methods are not very effective. On average, volley emissions by volume are $0.2-0.3 \%$ of the total amount of sewage from one enterprise, and by the total content of discharged sewage $-40-70 \%$. A volley discharge disrupts the operation of treatment plants and leads to irrecoverable losses of metals and valuable components $[1,2]$.

Traditional cleaning methods are considered and classified, which are shown in Fig. 1 for the purification of technological solutions of metalworking and machinebuilding industries.

Difficulties in solving environmental problems of metal-working and machinebuilding production are related to the diversified nature, territorial dispersion of these industries, low level of technical equipment, lack of unified technologies for coating, neutralization and waste disposal, and the lack of an integrated approach in the development, design, construction and operation of galvanic plants. 


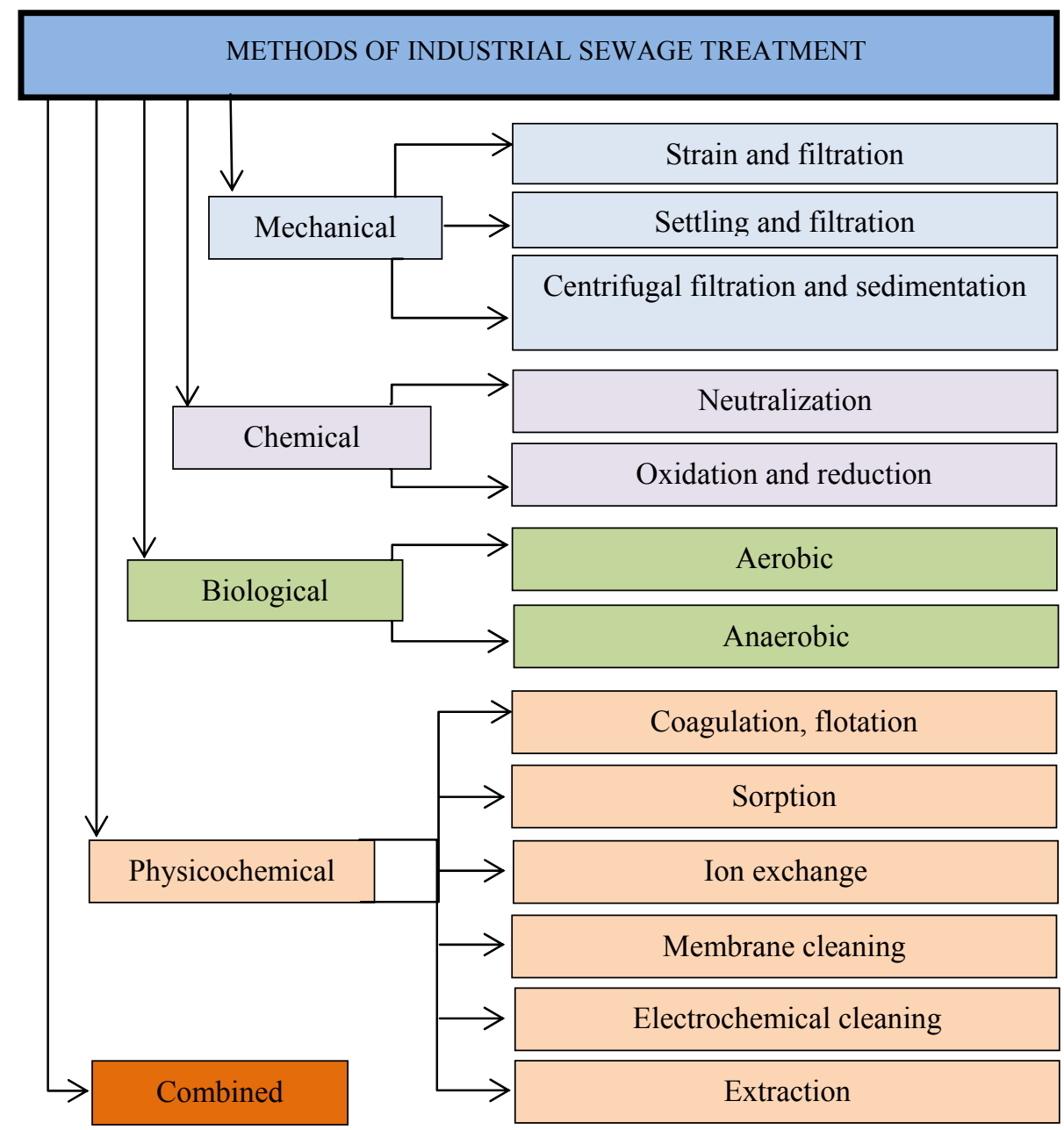

Fig. 1. Traditional cleaning methods for purification of technological solutions of metalworking and machine-building industries

The traditional methods of treatment considered are not universal, therefore the process of sewage treatment for metalworking and machine-building industries is mainly combined in existing enterprises, for example, combining ion exchange with electrolysis, electrolysis with electrodialysis, electroflotation with electrolysis, sorption with electrodialysis $[3,4]$.

Figure 2 shows a schematic diagram of a combined wastewater treatment method, which consists of the following stages: 1) neutralization - leveling of a certain $\mathrm{pH}$ value with $\mathrm{NaOH}, \mathrm{Ca}(\mathrm{OH})_{2}$, etc. for the chemical deposition of metals; 2) flocculation the addition of organic flocculants for the formation of macroflora; 3) precipitation to separate the solid phase, followed by dewatering of the sludge; 4) final post-treatment filtration, sorption or ion exchange.

The choice of the optimal method for wastewater treatment is quite a complicated task due to the diversity of pollutants in the water and the high demands placed on treated wastewater. When choosing the method of cleaning, not only their composition is taken into account, but also the requirements for purified water. The applied purification methods should ensure maximum use of treated wastewater in basic technological processes and their minimal discharge into the environment [3]. 


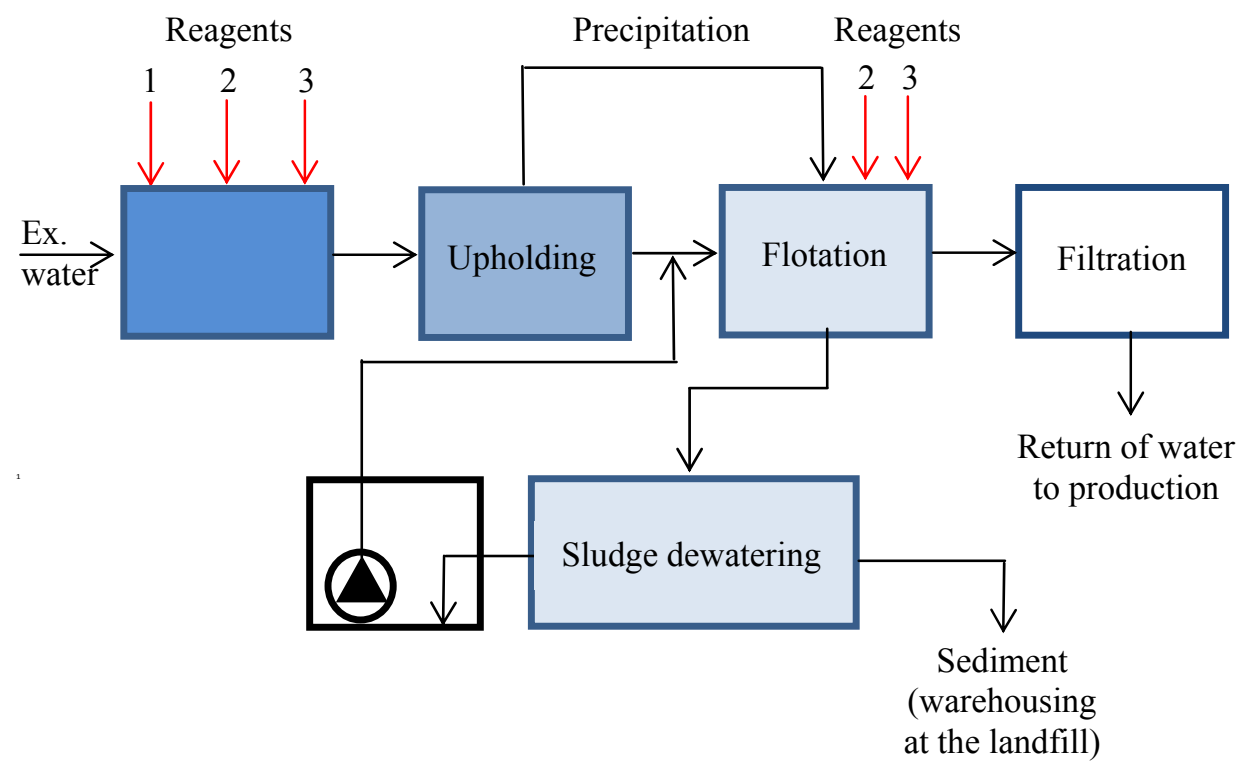

Fig. 2. Block diagram of a combined wastewater treatment

For further investigation, we chose the method of membrane separation of aqueous solutions. In membrane methods, the degree of water purification from mineral salts and heavy metals reaches $95-99 \%$, and purified solutions are returned to production in the order of up to $95 \%$.

The membrane separation systems of aqueous solutions are divided into groups according to the type of process being carried out (by driving force); by appointment; by the multiplicity of circulation; according to the number of stupae; on the organization of the flow of the separated mixture; on the mode of operation [5].

According to the variety of the process, plants are distinguished in which the driving force is the pressure difference on both sides of the membrane (micro-, ultra-, nanofiltration, hyperfiltration); electrodialysis; evaporation through the membrane; dialysis, etc. [6].

By appointment, industrial and pilot plants are identified to solve problems of clarification and purification, concentration, separation of process fluids.

By the multiplicity of circulation distinguish between direct flow and circulating membrane plants. Principally, there are two ways of carrying out the processes of membrane separation - deadlock and flow (Fig. 3) [6].

Deadlock membrane method under industrial conditions is rarely used, mainly on cartridge filter holders. However, with the use of regeneration of membrane cartridges by a reverse flow of the filtrate, it is possible to significantly expand the field of application of cartridge membrane systems.

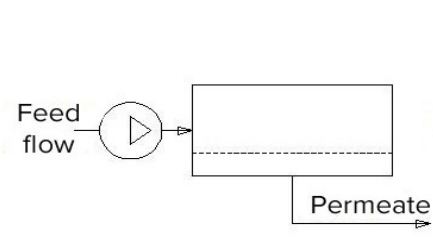

a)

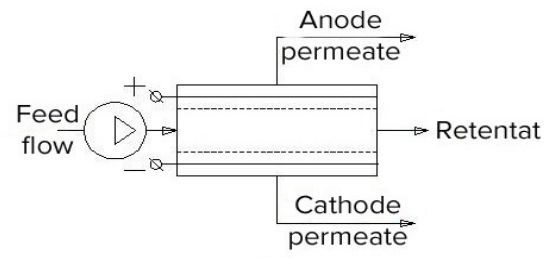

b)

Fig. 3. Membrane separation methods: $a$-deadlock; $b$ - flow 
In flow schemes, two flow configurations are used: a direct flow (Fig. 4, a) and a circulation flow (Fig. 4, $b$ ).

In straight flow membrane plants, the stock solution moves in the pressure channel of the membrane module once. In circulating membrane plants - repeatedly through a special circulation circuit with an additional circulating pump. They are used in cases where it is necessary to create high values of the tangential velocity above the surface of the membrane, thereby preventing the formation of a high-concentration (concentration-polarization) admixture layer.

The most significant kinetic characteristics that determine the rate of mass transfer in electromembrane processes are the following: current-voltage characteristics, diffusion permeability, output flux, rejection coefficientand the parameters of variation are current density, concentration of solute, magnitude of transmembrane pressure, and others.

To remove the current-voltage characteristics, a constant voltage was applied to the electrodes of the separation cell, which registered the current in the circuit stepwise. Figure 5 shows the dependence of the current density on the voltage for different concentrations of $\mathrm{Fe}^{2+}$ ions in the solution. Analysis of the dependence of the current density on the voltage at different concentrations (Fig. 5) showed that when the voltage increases, the current density increases. This is due to a directly proportional relationship between the current density and voltage.

The current density and voltage increased with increasing concentration of iron ions in the initial solution. This is due to the values of the investigated membrane stress, which depends on the membrane resistance, including the ohmic resistance of the space between the measuring electrodes, the resistance of the interface between the membrane and the solution.

The acetate-cellulose membranes work according to the passport at the $\mathrm{pH}$ range of $5-8$, the $\mathrm{pH}$ change in any direction causes destruction of the active layer, thereby reducing the service life of the membrane. At the pre-anode electrode (Fig. 6, a), an oxidation process takes place, thereby acidifying the solution, and a pre-cathodic electrode (Fig. $6, b$ ) undergoes a reduction process and the solution to be separated is basified. The change in the concentration in the initial solution does not affect $\mathrm{pH}$ so much as the voltage that enhances the oxidation and reduction processes.

In describing the process of mass transfer in membranes, it is necessary to know certain kinetic parameters of the membrane-solution system, which include the sorption capacity of membranes. This value characterizes the ability of the membrane to bind the solute, which in turn affects such a membrane parameter as the retention factor. Therefore, we investigated the effect of the process parameters (concentration of solute, temperature) on the sorption capacity of MGA-95 membranes, MGA-95P when the aqueous solution of chromium and copper was separated. Figure 7 shows sorption isotherms for MGA-95 membranes, MGA-100 for aqueous solutions of iron.

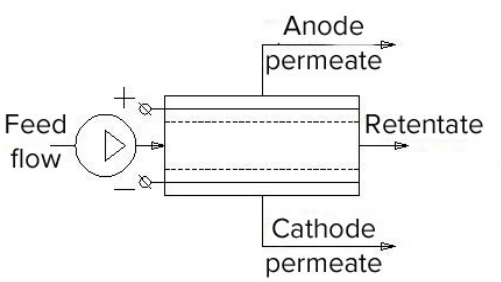

a)

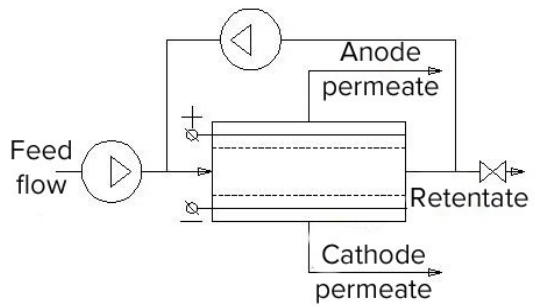

b)

Fig. 4. Functional diagrams of flow membrane plants: $a$ - direct flow; $b$ - circular flow 


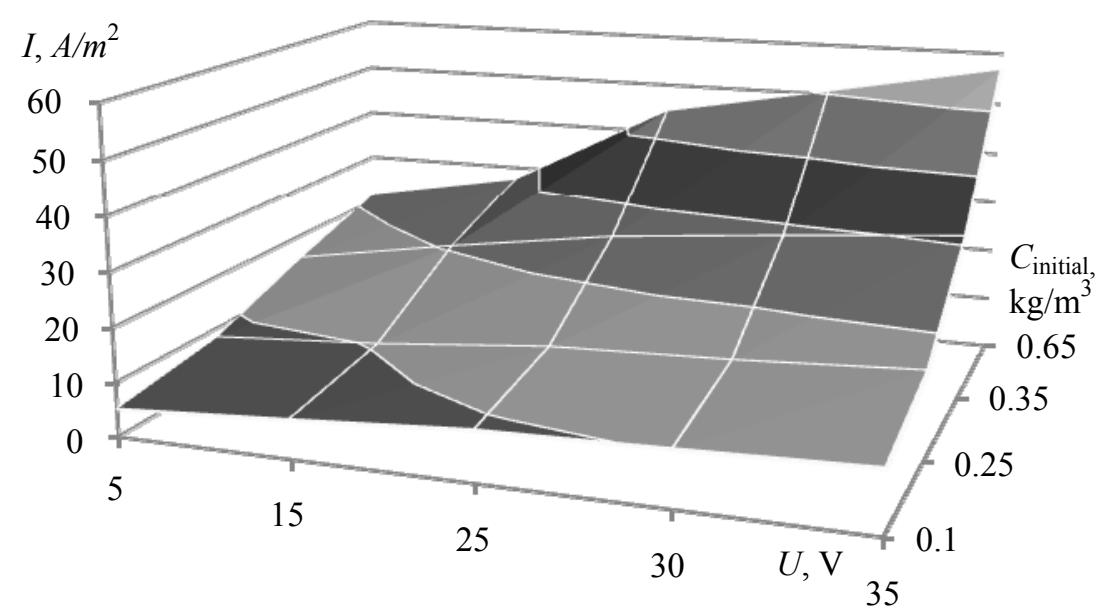

Fig. 5. Volt-ampere characteristics at different solution concentrations

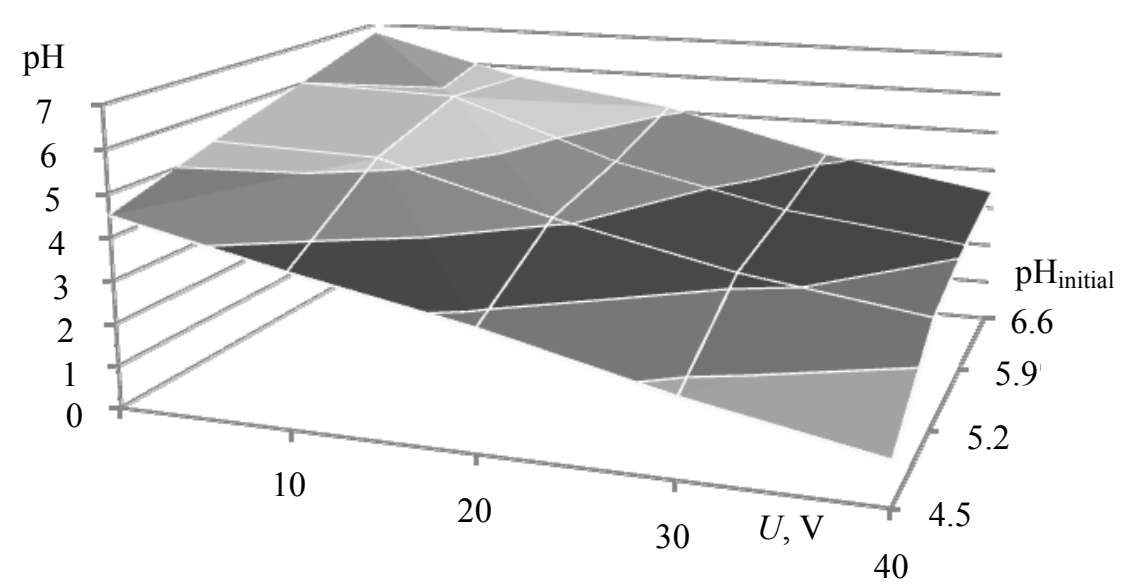

a)

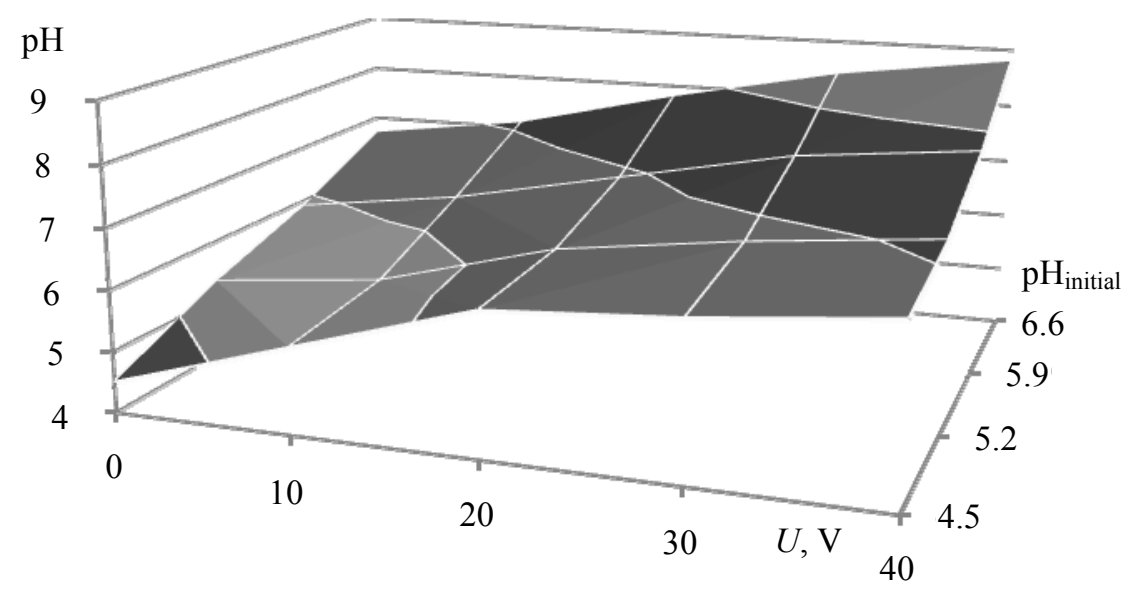

b)

Fig. 6. Dependence of $\mathrm{pH}$ solution on the voltage and the feed solution $\mathbf{p H}$ on the pre-anode $(a)$ and on the cathode $(b)$ membranes 


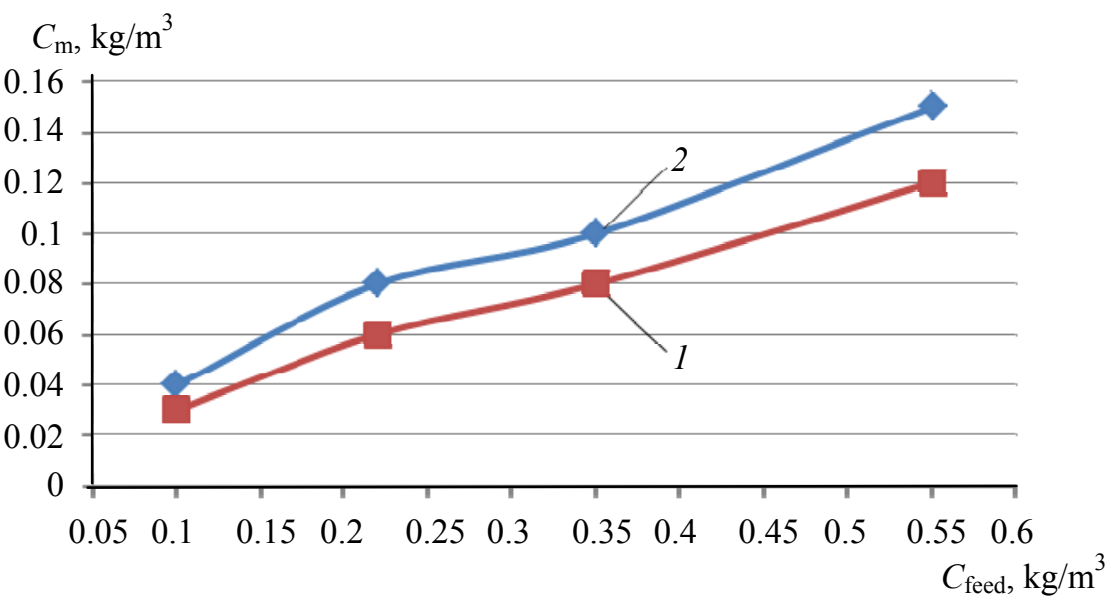

Fig. 7. Isotherms of membrane sorption for $\mathrm{Fe}^{2+}$ : 1 - MGA-100; 2 - MGA-95

For the sorption isotherms presented, the following is observed: as the concentration of the sorption capacity of the MGA-95 membranes increases, the MGA-100 for all investigated substances increases [7]. Different values of the sorption capacity of the membranes MGA-100 and MGA-95 are due to different porosity and production.

Many questions of diffusion permeability in membranes are explained on the basis of general positions of diffusion in polymer systems. It is known from the literature data $[8,9]$ that the diffusion permeability of membranes depends on a large number of factors: the structure of the polymeric membrane, the class of the dissolved substance and the nature of its interaction with the membrane, the concentration of the solute, the hydrodynamic conditions of the mass transfer process and etc.

Dependences of the diffusion permeability coefficient on the concentration of heavy metal $\mathrm{Fe}^{2+}$ are shown in Fig. 8 .

In analyzing the presented dependences, it can be noted that the value of the diffusion permeability coefficient of membranes for solutions containing iron ions decreases insignificantly with increasing concentration. This behavior of the diffusion

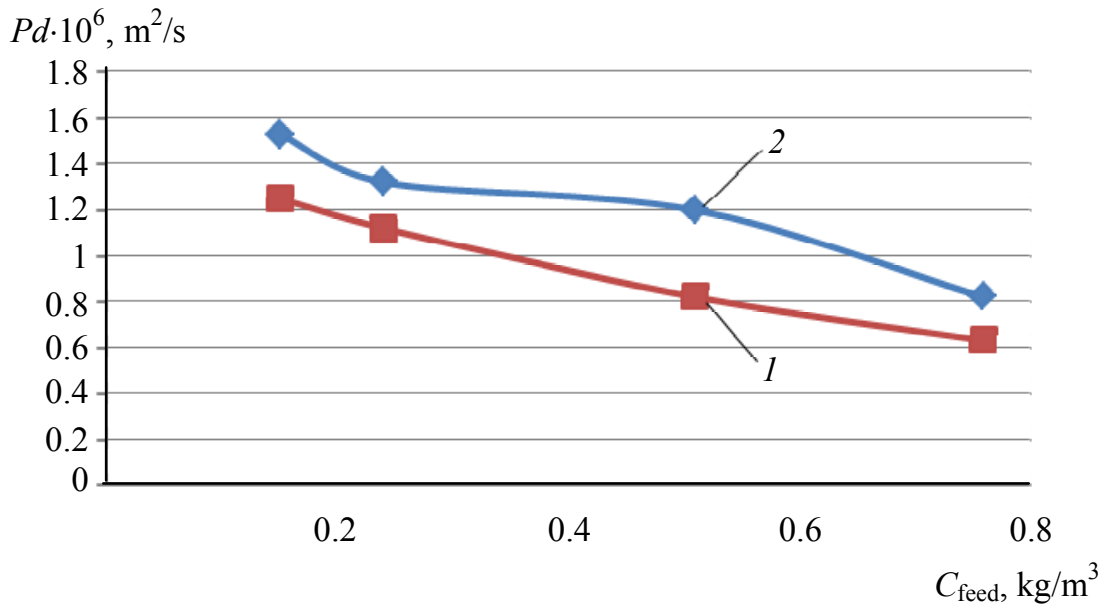

Fig. 8. Dependence of MGA-95 and MGA-100 membrane diffusion permeability coefficient on the concentration of the dissolved substance $\left(\mathrm{Fe}^{2+}\right)$ : 1 - MGA-100; 2 - MGA-95 
permeability can be explained by the different nature of the interaction of the dissolved substances with the membrane. The solute, which is inert to the membrane material, diffuses mainly through the pore space filled with the solution. The substance, which interacts with the membrane, penetrating into its matrix, except porous space, is transferred through the amorphous areas of the swollen membrane. For substances interacting with the membrane, as the concentration of the solution increases, the process of "loosening up" of the membrane probably results, the result of which is an increase in the coefficient of diffusion permeability.

According to diffusion permeability and sorption capacity, the experimental value of the diffusion coefficient of iron ions through semipermeable membranes was calculated by the formula

$$
D_{m}=\frac{P_{d} C_{\text {ucx }}}{\bar{C}},
$$

where $\bar{C}$ is the concentration of the substance in the membrane.

From the obtained experimental data, expressions were approximated for the theoretical calculation of the diffusion coefficient as a function of the concentration of the solution under study

$$
D_{m}=b C^{n},
$$

where $b, n$ are empirical coefficients.

Table 1 presents the empirical coefficients.

The output flow of membranes and the rejection coefficient are integral values depending on many factors (the nature of the solute and its concentration, the component composition of the solution, the hydrodynamics of the solution flow over the membrane, the temperature, etc. $[8,9])$.

The dependence of the output flux on the transmembrane pressure and the current density for the test solution $\left(\mathrm{Fe}^{2+}\right)$ is implicitly shown in Fig. 9. The magnitude of the output flux during resolution of the solutions is affected by the magnitude of the transmembrane pressure, current density, solution temperature, concentration of solute in solution and the nature of the solute.

Table 1

Values of empirical coefficients

\begin{tabular}{c|c|c|c}
\hline Membrane & Aqueoussolution & $b 10^{10}$ & $n$ \\
\hline MGA-100 & $\mathrm{Fe}^{2+}$ & 4.9141 & 0.1621 \\
\hline MGA-95 & $\mathrm{Fe}^{2+}$ & 3.9279 & 0.1808 \\
\hline
\end{tabular}

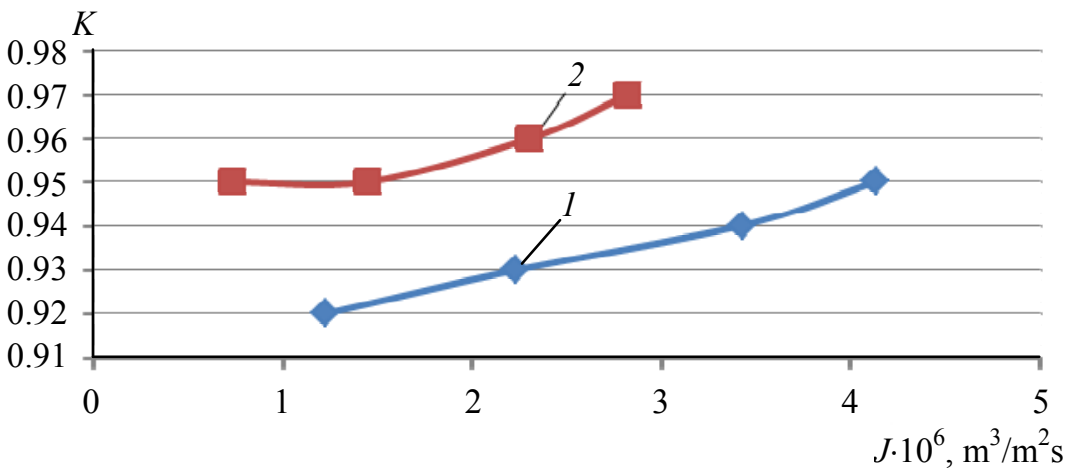

Fig. 9. Dependence of the retention coefficient of MGA-95 and MGA-100membranes on the output flux at $\triangle \mathrm{P}=1-4 \mathrm{MPa}$ : 1-MGA-95; 2 - MGA-100 
The analysis of the dependence of the output flux on the transmembrane pressure (Fig. 9) showed that with increasing transmembrane pressure, the permeability of membranes increases, because the effective driving force of the process increases [6]. Membrane MGA-95 has a large value of the output flux compared to MGA-100, which is explained by the different semipermeable structure of the active membrane membrane layer. Initially, for transmembrane pressure values that do not cause a change in the membrane structure, the permeability of water increases linearly with increasing effective driving force. However, with a further increase in pressure, the polymer membrane does not retain its original structure and is compacted. In this connection, starting from a certain value of the transmembrane pressure, the water-permeability reaches a maximum and decreases with a further increase in pressure [6].

Considering the dependence of the output flux on the current density (Fig. 10), it is noted that when an oxidation process takes place on the membrane, oxygen is formed, during the oxidation process, precipitating, sedimentation on the surface of membranes, etc. Where, in addition, due to the formation of oxygen, a partial blocking of the boundary layer and membrane pores takes place, as a result of the increase in the current density, the outlet flow on the near-anode membranes decreases.

For the theoretical calculation of the specific flux, an equation of the following form is proposed [7]:

$$
J=k\left(\Delta P-\left(k_{1}+i^{m} k_{2}\right) C\right) \exp \left(k_{3} C^{n}\right) \exp \left(\frac{A}{T}\right),
$$

where $k_{1}, k_{2}, k_{3}, n, A$ are numerical coefficients, $\Delta P$ is the difference of transmembrane pressure, $\mathrm{MPa}$; $C$ is the concentration, $\mathrm{kg} / \mathrm{m}^{3} ; T$ is the temperature, $K ; k$ is the water permeability coefficient of the membrane, $\mathrm{m} / \mathrm{s} \cdot \mathrm{MPa} ; i$ is the current density $\left(\mathrm{A} / \mathrm{m}^{2}\right)$.

Table 2 shows the values of the empirical coefficients for the calculations by Equation 3.

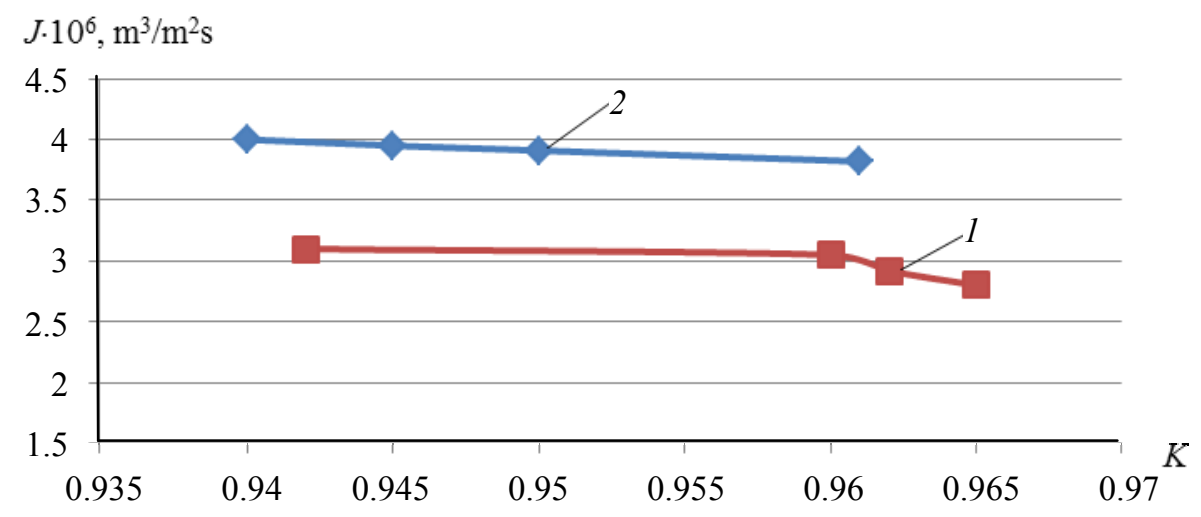

Fig. 10. Dependence of the output flux of MGA-95 and MGA-100 membranes on the retention rate at $i=20.2 ; 39.7 ; 51.7 ; 60.2 \mathrm{~A} / \mathrm{m}^{2}$ on the pre-anode membrane: 1 - MGA-100; 2 - MGA-95

Table 2

The values of the empirical coefficients for the expression (3)

\begin{tabular}{c|c|c|c|c|c|c}
\hline Membrane & $k_{1}$ & $m$ & $k_{2}$ & $k_{3}$ & $n$ & $A$ \\
\hline MGA-95 & -0.94 & 0.51 & 0.10 & 6.54 & 1.00 & 6.54 \\
\hline MGA-100 & 0.73 & -0.20 & 4.29 & 7.16 & 4.72 & 4.74 \\
\hline
\end{tabular}


The values of the empirical coefficients used in the calculations using equation (4)

\begin{tabular}{|c|c|c|c|c|}
\hline Solution & Membrane & $k_{1}$ & $k_{2}$ & $k_{3}$ \\
\hline \multirow{2}{*}{$\mathrm{Fe}(\mathrm{II})$} & MGA-95 & 0.054 & 1.012 & 32.14 \\
\cline { 2 - 5 } & MGA-100 & 4.12 & 0.24 & 1.08 \\
\hline
\end{tabular}

An important kinetic parameter of the process of electroperfiltration is the rejection coefficient. This parameter depends on many factors: the type of membranesolution system, pressure, temperature and concentration and the hydrodynamics of the process [4].The dependence of the rejection coefficient on the transmembrane pressure, concentration and current density for the solutions under study is shown in Fig. 9, 10.

Analyzing the dependence of the rejection coefficient on the magnitude of the transmembrane pressure in Fig. 9, it can be noted that the rejection coefficient increases with the increase in transmembrane pressure. With the increase in the transmembrane pressure, the hydrodynamic force increases, which increases the water flow acting on the active layer of the membrane, as a result of deformation, the membrane is compacted, which leads to a decrease in the pore diameter [7].

The rejection coefficient also depends on the current density (Fig. 10), it is noted that as the current density rises, the rejection coefficient increases, this phenomenon is probably caused by an increase in the ion flux with increasing current density [3].

For the theoretical calculation of the rejection coefficient with the imposition of an electric potential, an expression of the following form was obtained [3]:

$$
R=1-\frac{1}{1+\left(\frac{1}{k_{1} k_{p}}-1\right)\left[1-\exp \left(\frac{k_{2} J k_{p} i \eta}{D k_{p} i \eta}\right)\right] \exp \left(-k_{3} J\right)},
$$

where $k_{1}, k_{2}, k_{3}$ are empirical coefficients; $i$ is the current density, $\mathrm{A} / \mathrm{m}^{2} ; \eta$ is the current output; $D$ is the diffusion coefficient, $\mathrm{m}^{2} / \mathrm{s}$.

Table 3 shows the values of the empirical coefficients for expression 4.

The discrepancy between the experimental and calculated values is no more than $20 \%$. On the basis of the conducted studies and the presented analysis of the experimental data on some kinetic relationships, it can be concluded that in the process of electrohyperfiltration, it is possible to efficiently separate and extract metals from industrial and technological solutions of metal-processing and machine-building industries.

\section{References}

1. Zubchenko V.L., Zakharov V.I., Rogov V.M. Flexible automated electroplating lines : a Handbook, Moscow, 1989, 672 p. (In Russ.)

2. Vinogradov S.S. Rinsing and Washing operations in the electroplating production, Moscow, 2007, 156 p. (In Russ.)

3. Kiseleva N. V. Chemical treatment of wastewater of electroplating from ions of heavy metals, Kazan', 1999, 237 p. (In Russ.)

4. Yakovlev S.V., Krasnoborodko I.G., Rogov V.M. Technology of electrochemical water treatment, Leningrad, 1987, 312 p. (In Russ.)

5. Kovalev S.V., Lazarev S.I., Lazarev K.S., Popov R.V. [The Specific flow rate and the coefficient of detention of a membrane MGA-95 with electropermanent the separation of an aqueous solution of zinc sulfate], Transactions of the Tambov State Technical University, 2015, vol. 21, no. 1, pp. 112-120. (In Russ., abstract in Eng.) 
6. Lutsenko M.M. Improving the technology of wastewater treatment electroplating plants from ions of Nickel and copper, St. Petersburg, 2004, 165 p. (In Russ.)

7. Akulinichev A.M., Abonosimov O.A., Lazarev S.I., Krasnova A.V. [Study of kinetic coefficients for the reverse osmosis separation of als-remineralizing solutions of wastewater], Bulletin of Tambov University, 2014, vol. 19, issue. 3, pp. 941-943. (In Russ., abstract in Eng.)

8. Akulinichev A.M., Abonosimov O.A., Lazarev S.I. A [Study Electrobalance Separation Industrial Process Solutions Containing Heavy Metal ions of $\mathrm{Pb}, \mathrm{Cd}, \mathrm{Fe}]$, Transactions of the Tambov State Technical University, 2017, vol. 23, no. 1, pp. 120-128. (In Russ., abstract in Eng.)

9. Shaposhnik V.A. [Membrane Electrochemistry], Smazochno-okhlazhdayushchaya zhidkost' [Lubricating-cooling Liquid], 2002, no. 8, pp. 38-42. (In Russ.)

\title{
НЕКОТОРЫЕ КИНЕТИЧЕСКИЕ ЗАВИСИМОСТИ ЭЛЕКТРОГИПЕРФИЛЬТРАЦИОННОГО МЕТОДА ОЧИСТКИ СТОЧНЫХ ВОД ОТ ИОНОВ ЖЕЛЕЗА
}

\author{
А. А. Левин ${ }^{1}$ О. А. Абоносимов ${ }^{1}$, С. И. Лазарев ${ }^{1}$, \\ О. А. Ковалева ${ }^{1}$, И. В. Хорохорина ${ }^{2}$, М. А. Кузнецов ${ }^{1}$ \\ Кафедры: «Прикладная геометрия и компьютерная графика» (1), \\ «Природопользование и защита окружающей средыл» (2), \\ ФГБОУ ВО «ТГТУ», г.Тамбов, Россия; geometry@mail.nnn.tstu.ru
}

Ключевые слова: выходной поток; кинетические зависимости; коэффициент задержания; мембрана; плотность тока; раствор; трансмембранное давление; установка.

Аннотация: Показана возможность применения электрогиперфильтрационного разделения при очистке сточных вод от ионов железа. Задачами работы являлось изучение влияния рабочих параметров процесса разделения исследуемого раствора на некоторые кинетические характеристики (вольт-амперные характеристики, выходного потока, коэффициента задержания, коэффициента диффузионной проницаемости и сорбционной способности мембран МГА-80, МГА-95 и МГА-100) электрогиперфильтрационного разделения сточных вод гальванических металлообрабатывающих производств. Выявлены закономерности изменения коэффициента задержания, выходного потока, коэффициента диффузионной проницаемости и сорбционной способности мембран в зависимости от плотности тока, величины трансмембранного давления, температуры и типа мембраны для исследуемого раствора. Представлены интерпретация и обобщение экспериментальных зависимостей некоторых кинетических зависимостей от параметров проведения процесса разделения.

\section{Список литературь}

1. Гибкие автоматизированные гальванические линии : справочник / В. Л. Зубченко, В. И. Захаров, В. М. Рогов и др.; под общ. ред. В. Л. Зубченко. М. : Машиностроение, 1989. $-672 \mathrm{c}$.

2. Виноградов, С. С. Промывные операции в гальваническом производстве / С. С. Виноградов. - М. : Глобус, 2007. - 156 с. 
3. Киселева, Н. В. Реагентная очистка сточных вод гальванического производства от ионов тяжелых металлов / Н. В. Киселева. - Казань, 1999. - 237 с.

4. Яковлев, С. В. Технология электрохимической очистки воды / С. В. Яковлев, И. Г. Краснобородько, В. М. Рогов. - Л. : Стройиздат, 1987. - 312с.

5. Удельный поток и коэффициент задержания мембраны МГА-95 при электробаромембранном разделении водного раствора сульфата цинка / С. В. Ковалев [и др.] // Вестн. Тамб. гос. техн. ун-та. - 2015. - Т. 21, № 1. - С. 112 - 120.

6. Луценко, М. М. Совершенствование технологии очистки стоков гальванических производств от ионов меди и никеля / М. М. Луценко. - СПб, 2004. - 165 с.

7. Исследование кинетических коэффициентов обратноосмотического разделения слабоминерализированных растворов сточных вод / А. М. Акулинчев [и др.] // Вестн. Тамб. ун-та. - 2014. - Т. 19, вып. 3. - С. 941 - 943.

8. Акулинчев, А. М. Исследование электробаромембранного разделения промышленных технологических растворов, содержащих ионы тяжелых металлов $\mathrm{Pb}, \mathrm{Cd}, \mathrm{Fe} / \mathrm{A.} \mathrm{М.} \mathrm{Акулинчев,} \mathrm{О.} \mathrm{А.} \mathrm{Абоносимов,} \mathrm{С.} \mathrm{И.} \mathrm{Лазарев} \mathrm{//} \mathrm{Вестн.} \mathrm{Тамб.} \mathrm{гос.}$ техн. ун-та. - 2017. - Т. 23, № 1. - С. $120-128$.

9. Шапошник, В. А. Мембранная электрохимия / В. А. Шапошник // Смазочно-охлаждающая жидкость. -2002 . - № $8 .-$ С. 38 - 42 .

\section{Einige kinetische Abhängigkeiten des Elektrohyperfiltrationsverfahrens zur Reinigung der Abwässer von Eisenionen}

Zusammenfassung: Es ist die Möglichkeit der Anwendung der Elektrohyperfiltrationstrennung bei der Reinigung der Abwässer von Eisenionen gezeigt. Die Aufgabe der Arbeit war es, die Auswirkungen der Arbeitsparameter des Prozesses der Trennung der $\mathrm{zu}$ untersuchenden Lösung auf einige kinetische Eigenschaften (Volt-Ampere Eigenschaften, Ausgangsstrom, Festhaltequoten, Diffusionsdurchlässigkeit und Sorptionskapazität der Membranen MGA-80, MGA-95 und MGA-100) der Elektrohyperfiltrationstrennung der galvanischen metallverarbeitenden Abwasserproduktionen $\mathrm{zu}$ untersuchen. Es sind die Regelmäßigkeiten der Veränderung des Festhaltekoeffizienten, des Ausgangsstroms, der Diffusionsdurchlässigkeit und der Sorptionskapazität der Membranen in Abhängigkeit von der Stromdichte, der Größe des Transmembrandruckes, der Temperatur und der Art der Membran für die zu untersuchende Lösung aufgedeckt. Es sind die Interpretation und Verallgemeinerung der experimentellen Abhängigkeiten einiger kinetischer Abhängigkeiten von den Trennungsoptionen vorgestellt.

\section{Certains dépendances cinétiques de la méthode électrique d'hyperfiltration du traitement des eaux usées des ions de fer}

Résumé: Est montrée la possibilité d'appliquer une séparation électrique d'hyperfiltration du traitement des eaux usées des ions de fer. L'objectifs du travail était d'étudier l'impact des paramètres du fonctionnement du processus de la séparation de la solution étudiée sur certaines caractéristiques cinétiques (caractéristiquesvolt-ampères, flux de sortie, taux de rétention, coefficient de diffusion de la perméabilité et capacité de sorption des membranes MGA-80, MGA-95 et MGA-100) de la séparation électrique d'hyperfiltration du traitement des eaux usées industrielles. Sont révélés des modèles de la variation du coefficient de rétention, du flux de sortie, du coefficient de perméabilité 
de diffusion et de la capacité de sorption des membranes en fonction de la densité du courant, de la valeur de la pression transmembrane, de la température et du type de membrane pour la solution étudiée. Sont présentées l'interprétation et la synthèse des dépendances expérimentales de certaines dépendances cinétiques des paramètres du processus de la séparation.

Авторы: Левин Александр Александрович - аспирант кафедры «Прикладная геометрия и компьютерная графика»; Абоносимов Олег Аркадьевич доктор технических наук, доцент кафедры «Прикладная геометрия и компьютерная графика»; Лазарев Сергей Иванович - доктор технических наук, профессор, заведующий кафедрой «Прикладная геометрия и компьютерная графика»; Ковалева Ольга Александровна - кандидат технических наук, докторант кафедры «Прикладная геометрия и компьютерная графика»; Хорохорина Ирина Владимировна - кандидат технических наук, доцент кафедры «Природопользование и защита окружающей среды»; Кузнецов Михаил Александрович - доктор технических наук, доцент, профессор кафедры «Прикладная геометрия и компьютерная графика», ФГБОУ ВО «ТГТУ», г. Тамбов, Россия.

Рецензент: Ковалев Сергей Владимирович - доктор технических наук, доцент кафедры «Прикладная геометрия и компьютерная графика», ФГБОУ ВО «ТГТУ», г. Тамбов, Россия. 